Dicle Tıp Dergisi / Dicle Med J (2019) 46 (4) : 885-888

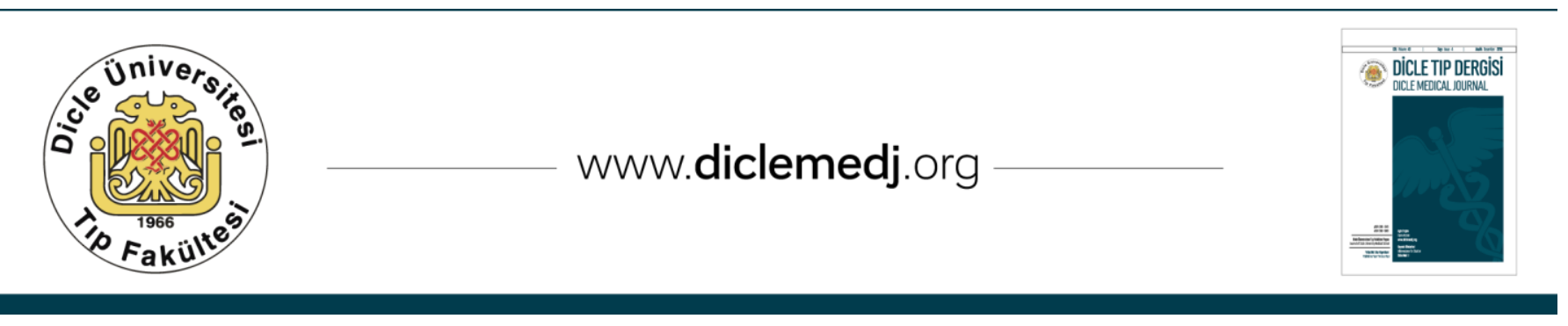

Olgu Sunumu / Case Report

\title{
Gallbladder Duplication in Two Cases
}

\author{
Sefa Sag1, Hatice Sonay Yalcin Comert ${ }^{2}$, Mustafa Imamoglu ${ }^{3}$ \\ 1 University of Health Sciences, Kanuni Education and Research Hospital, Dept. of Pediatric Surgery, Trabzon, Turkey ORCID: 0000-0002-0904-315X \\ 2 Karadeniz Technical University Medical Faculty, Department of Pediatric Surgery, Trabzon, Turkey ORCID: 0000-0002-5281-4933 \\ 3 Karadeniz Technical University Medical Faculty, Department of Pediatric Surgery, Trabzon, Turkey ORCID: 0000-0002-9521-1024 \\ Received: 16.07.2019; Revised: 05.08.2019; Accepted: 19.09.2019
}

\begin{abstract}
Gallbladder duplication is very rare congenital malformation that is usually asymptomatic, but which may present with various complications. We present here two cases gallbladder duplication who presented with cholestatic hepatitis-acute abdomen in early childhood and treated with surgery, and the second one was asymptomatic during the follow-up who were detected in intrauterine period. The treatment of gallbladder duplication must be carefully managed. Unnecessary surgery should be avoided in asymptomatic cases, while in symptomatic patients requiring surgery it is important to clearly reveal the biliary system and vascular anatomy and to remove both gallbladders.
\end{abstract}

Keywords: acute abdomen, child, double gallbladder, surgery

\section{İki Olguda Safra Kesesi Duplikasyonu}

\section{Öz}

Safra kesesi duplikasyonları genellikle asemptomatik olan ancak neden olduğu çeşitli komplikasyonlarla da tanı konulabilen çok nadir görülen konjenital malformasyonlardır. Bu yazıda erken çocukluk döneminde kolestatik hepatit-akut karın bulguları ile başvuran ve cerrahi müdahale ile tedavi edilen ve intrauterin dönemde saptanan, izlem sırasında asemptomatik olan iki safra kesesi duplikasyonlu olgu sunulmaktadır. Safra kesesi duplikasyonunun izlem ve tedavisi dikkatli bir şekilde yapılmalıdır. Asemptomatik olgularda gereksiz ameliyatlardan kaçınılmalı, cerrahi müdahale gerektiren semptomatik olgularda ise biliyer sistem ve vasküler anatomi net şekilde ortaya konulmalı ve operasyon sırasında her iki safra kesesi birden çıkarılmalıdır.

Anahtar kelimeler: akut karın, çocuk, safra kesesi duplikasyonu, cerrahi

DOI: $10.5798 /$ dicletip.

Yazışma Adresi / Correspondence: Sefa Sag, University Of Health Sciences, Kanuni Education and Research Hospital, Department of Pediatric Surgery, Trabzon, Turkeye-ail: drsefa51@gmail.com 


\section{INTRODUCTION}

Gallbladder duplication is a rare malformation that seems in $1 / 4000$ births $^{1}$. It is usually asymptomatic and may present with various complications such as cholestasis, cholecystitis. It is suggested that symptomatic duplication cysts should be removed. Preoperative imaging is often helpful for diagnosis and important for prevention of possible surgical complications ${ }^{2}$. We aimed to share two patients who presented with cholestatic hepatitis and received surgical treatment in the early childhood period and the second one was asymptomatic during the follow-up who were detected in intrauterine period.

\section{CASE 1}

A five years old boy was admitted to the hospital with abdominal pain which located on the right upper quadrant for 15 days and nausea - vomiting for two days. In the physical examination; He had sensitivity in the right upper quadrant of abdomen. After radiologic examination, ultrasound (USG) revealed a cystic mass with $20 \times 30 \mathrm{~mm}$ size and not associated with common bile duct. Magnetic resonance cholangiopancreatography (MRCP) was performed for differential diagnosis and MRCP revealed a $27 \times 24 \mathrm{~mm}$ cystic structure (duplication cyst?) attached to the gallbladder, and minimal dilatation in the intrahepatic biliary tract (Figure 1). Laboratory analysis revealed cholestatic hepatitis; alanin aminotransferase (ALT) $498 \mathrm{U} / \mathrm{L}$, aspartate aminotransferase $255 \mathrm{U} / \mathrm{L}$, gamma glutamyl transferase (GGT) $352 \mathrm{U} / \mathrm{L}$, alkaline phosphatase $491 \mathrm{U} / \mathrm{L}$ total / direct bilirubin 0.56 / $0.14 \mathrm{mg} / \mathrm{dl}$ and C-reactive protein 0.2 $\mathrm{mg} / \mathrm{dl}$. Surgery was planned for the patient and performed by right subcostal incision. Then, duplicate gallbladder was explored. It was seen that one of the gallbladder was hydropic and pressing to the intrahepatic area. Both gallbladders were excised with a careful dissection and the common cystic duct was ligated at the level of choledochus, and cholecystectomy was performed finally (Figure 2). On the post-operative second day, it was seen that ALT decreased to $113 \mathrm{U} / \mathrm{L}$ and GGT to $15 \mathrm{U} / \mathrm{L}$. The patient was discharged on the third day after the operation. In the histopathologic examination; "gall bladder duplication and chronic cholecystitis" were detected.

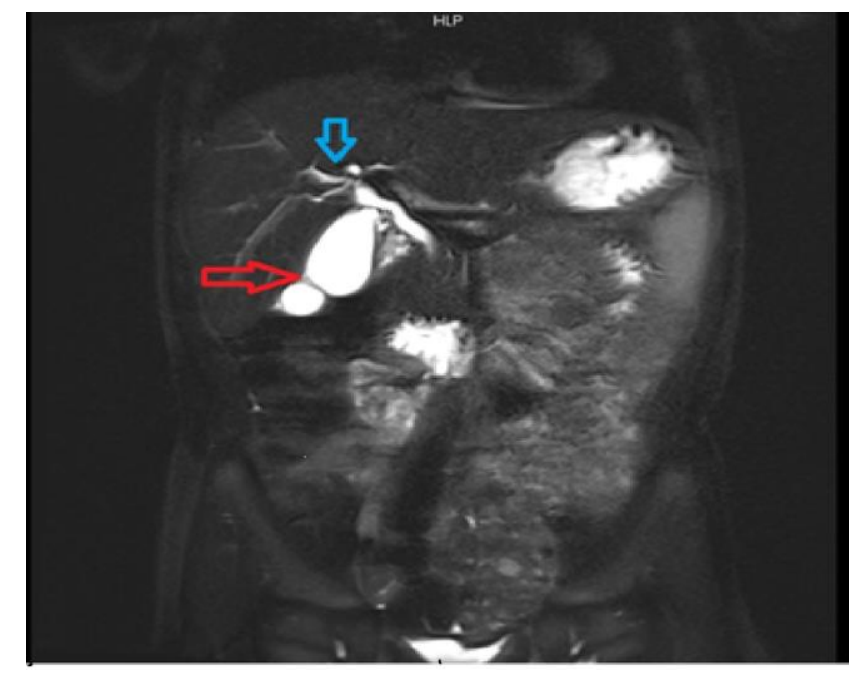

Figure 1: Magnetic resonance cholangiopancreatography image of the first case (duplicated sac arrowed with red and intrahepatic biliary dilatation arrowed with blue)

\section{CASE 2}

A one year-old male patient had intrauterine cystic enlargement of the biliary tract that detected in the intrauterine 28th weeks period. There was no pathological finding suggesting cholestasis in the blood analyze but USG revealed the dilatation in the extrahepatic biliary duct (choledochal cyst?, duplication cyst? ) after birth. MRCP was performed for the different diagnosis and revealed a double gallbladder with normal size and wall thickness which joined at the level of the neck and opened to cystic duct (Figure 3). During the follow up at first year, the patient's laboratory values were normal and he was asymptomatic. So, we planned to check up the patients with six months intervals.

Informed consents were received from the families. 


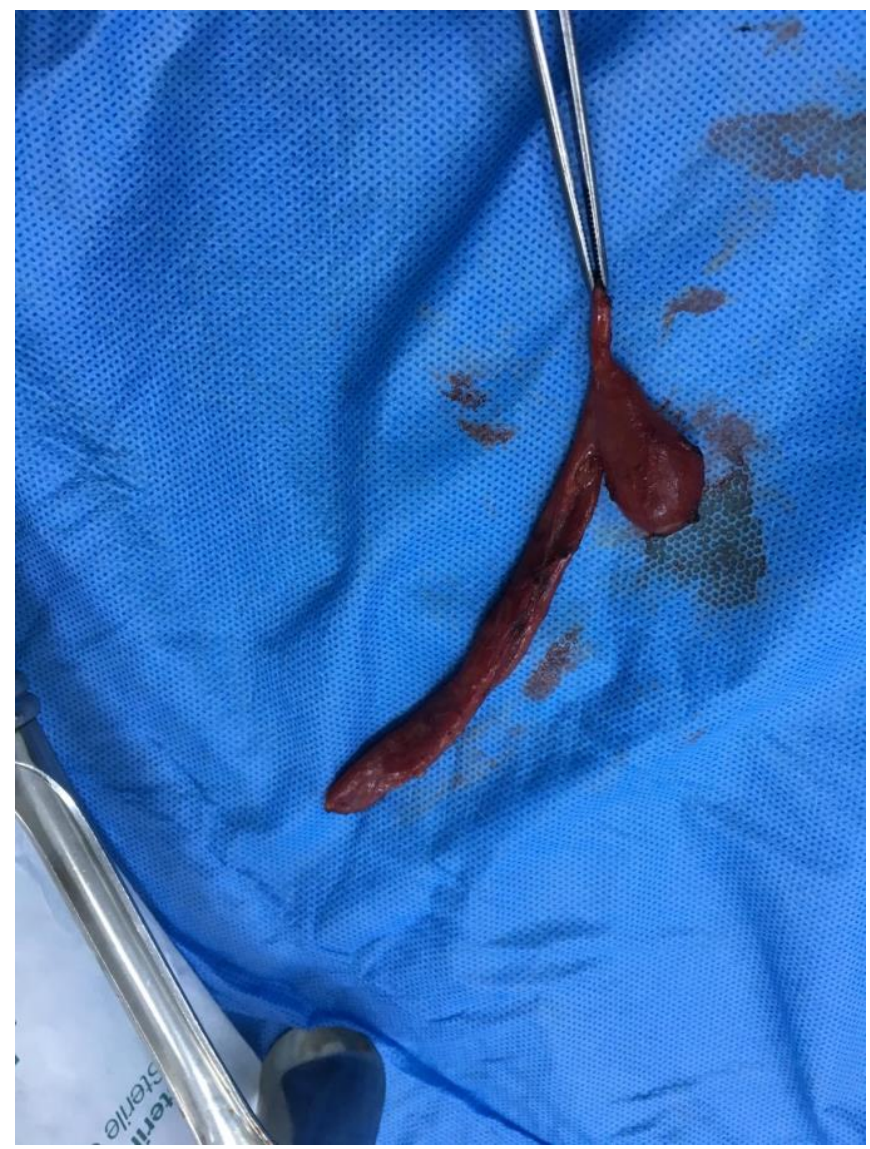

Figure 2: Intraoperative imaging of gallbladder duplication in Case 1

\section{DISCUSSION}

Gallbladder duplication is a rare malformation. It is classified as vesica fellea divisa (double gallbladder with a common neck) and vesica fellea duplex (double gallbladder with two cystic ducts) ${ }^{1}$. The possible pathology may explain through a defect that occurs during the division of the caudal bud of the hepatic diverticulum and the budding of the developing biliary system in intrauterine life $^{3}$. In both of our cases, we had a double pouch and middle cystic canal which was opened to choledoch. So, we thought that our cases had vesica fellea divisa type of gallbladder duplication.

These malformations are usually asymptomatic and may present with complications such as acute or chronic cholecystitis, torsion, cholocystocytic fistula and carcinoma. In addition, they may also cause stasis in the bile ducts $^{2}$. Our first case was admitted to the hospital with cholestasis, elevated liver enzymes and acute abdomen findings. The second case was asymptomatic. In general, it is suggested that symptomatic duplication cysts should be removed but near that asymptomatic cysts should be followed up ${ }^{2}$. Unnecessary surgery should be avoided as there is no difference between the complication rates of normally sac and duplicate sac. When cholecystectomy is performed, both gallbladders should be removed. If both pouches are not removed, symptoms may persist and may need reoperation ${ }^{3}$. The first case was operated because of cholestasis. The both gallbladder carefully removed from the peritoneum and cholecystectomy was performed. It was observed that the stasis improved and the liver enzymes returned to normal values rapidly after surgery. The other patient who was asymptomatic did not operated and has been following up.

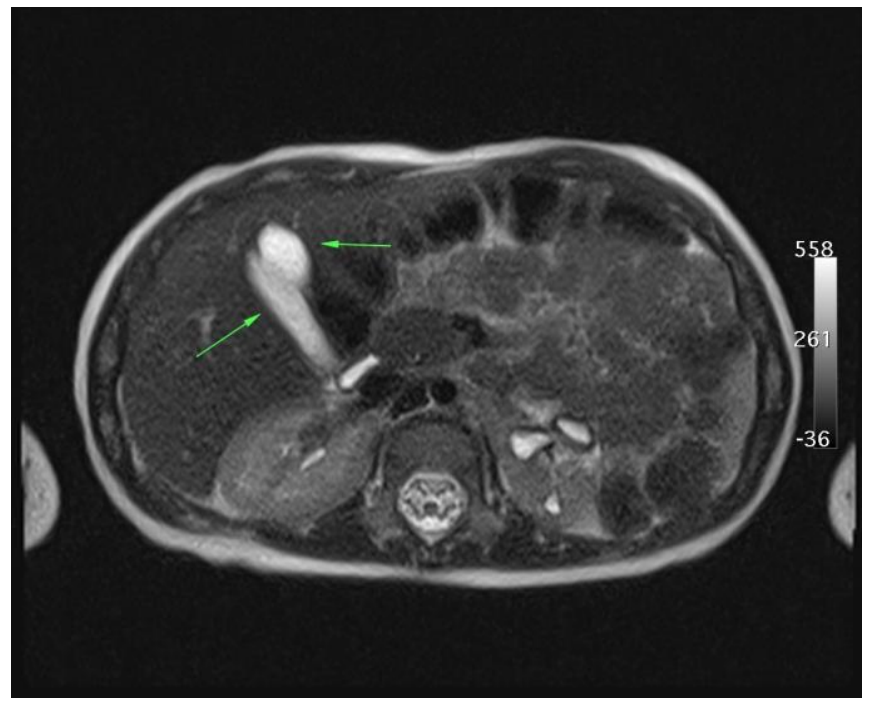

Figure 3: Magnetic resonance cholangiopancreatography image of the second case

It is common for gallbladder duplication to remain undetected prior to cholecystectomy ${ }^{4}$ and this condition occurs a high risk during operation about intraoperative biliary and 
vascular injury 5 . It is also important to consider the differential diagnoses for gallbladder duplication prior to resection, which include choledochal cyst, gallbladder diverticulum, pericholecystic fluid, phrygian cap, focal adenomyosis $^{6}$. In suspected cases, it is important to examine the biliary system fully with the help of supporting diagnostic tools ${ }^{1}$. USG is currently the primary imaging modality for suspected gallbladder disease. However, USG imaging does not always allow a precise diagnosis of gallbladder malformations. USG may demonstrate wall thickness, lumen pathology and the number of the gallbladders but is unable to define always the exact anatomy of the biliary tree. Computer tomography is also available as simple imaging modality of double gallbladder but in some cases it may not be enough. MRCP is a noninvasive technique widely used in the evaluation of biliary tract abnormalities because of its lack of radiation effect and show biliary system detailed. In our cases MRCP showed the gallbladder duplication and allowed us determine the type of duplication ${ }^{7}$.

In conclusion; gallbladder duplication is a malformation that must be careful in management. Although most of them are asymptomatic, they may present with various complications such as cholestatic hepatitis. Unnecessary surgery should be avoided in asymptomatic cases. In the symptomatic cases requiring surgery, it is important to clearly reveal the biliary system and vascular anatomy and remove both gallbladder.

Conflict of interest and financial disclosure statement: We declare that they have no conflict of interest and financial disclosure.

Declaration of Conflicting Interests: The authors declare that they have no conflict of interest.

Financial Disclosure: No financial support was received.

\section{REFERENCES}

1. Roldan VE, Osorio PS, Vivas BI, et al. Asymptomatic true gallbladder duplication: a case report and review of literature. Acta Radiol. 2004; 45: 810-4.

2. Pillay Y. Gallbladder duplication. Int J Surg Case Rep. 2015; 11: 18-20.

3. Bhoil R, Jhobta A, Aggarwal N, Kumar N. Asymptomatic true gallbladder duplication. Dig Liver Dis. 2016; 48: 97.

4. Hishinuma M, Isogai $Y$, Matsuura $Y$, et al. Double gallbladder. J. Gastroenterol Hepatol. 2004; 19: 233-5.

5. Wong C, Mason S, Bowden D, Brais R, Harper S. An unusual variation of gallbladder duplication originating from the right hepatic duct. Int J Surg Case Rep. 2018; 51: 181-5.

6. Gigot J, Van BB, Goncette L. Laparoscopic treatment of gallbladder duplication. A plea for removal of both gallbladders. Surg. Endosc. 1997; 11; 479-82.

7. Vitellas KM, Keogan MT, Spritzer CE, Nelson RC. Mr cholangiopancreatography of bile and pancreatic duct abnormalities with emphasis on the single-shot fast spin-echo technique. Radiographics. 2000;20: 93957;quiz1107-1108,1112. 